\title{
Annular pancreas
}

INSERM

\section{Source}

INSERM. (1999). Orphanet: an online rare disease and orphan drug data base. Annular pancreas. ORPHA:675

Annular pancreas is a distinct form of duodenal atresia (see this term) in which the head of the pancreas forms a ring around the second portion of the duodenum. 